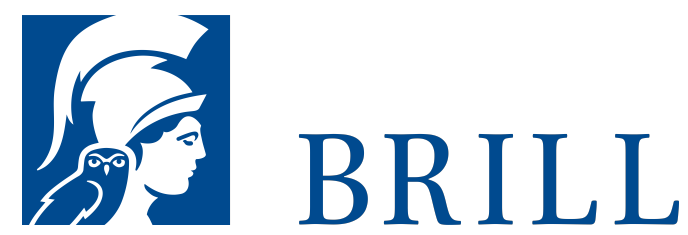

\title{
Medien der Unmittelbarkeit
}

Dingkonzepte und Wahrnehmungstechniken 1918-1939

Author: Tobias Wilke

Medialität scheint Unmittelbarkeit per definitionem auszuschließen - und doch ist es gerade der Zusammenhang dieser beiden Phänomene, der in den 192oer und 193oer Jahren zu Brennpunkt der beginnenden Medienreflexion avanciert. Von Hugo Münsterberg bis Rudolf Arnheim, von Fritz Heider bis Lásló Moholy-Nagy, von Béla Balázs bis Walter Benjamin reichen die Versuche, jenes Verhältnis psychologische und ästhetisch zu konzipieren. Indem sie das Spannungsfeld von dringlicher Wahrnehmungswelt, technischen Apparaturen und menschlichem Sensorium neu kartieren, bringen sie "Medien der Unmittelbarkeit" hervor.

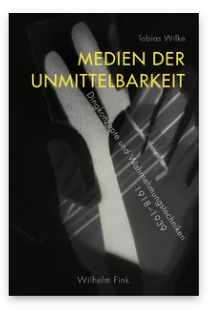

Pages: 259

Seiten, $22 \mathrm{~s} / \mathrm{w}$

Abb.

Language:

German

Publisher: Brill | Fink

E-Book (PDF)

Released online: o7 Oct 2019

ISBN: 978-3-

8467-4923-4

List price

USD $\$ 60.00$

Paperback

Publication date:

17 Mar 2010

ISBN: 978-3-

7705-4923-8

List price

USD $\$ 60.00$ 
For more information see brill.com

Order information: Order online at brill.com +44330 333 0049 | customerservices@brill.com Submission information: brill.com/authors

Titles published by Brill | Fink, Brill | mentis or Brill | Schöningh: +49(o)715413279216| brill@brocom.de 